\title{
Kilka uwag na tle kompensacyjnej funkcji prawa karnego
}

\author{
Emil W. PŁywaczewski \\ Ewa M. GuZIK-MaKaruK \\ Katedra Prawa Karnego \\ Uniwersytet w Białymstoku
}

I. Opracowanie niniejsze dedykujemy Szacownemu Jubilatowi - Profesorowi Tomaszowi Kaczmarkowi - wychowawcy wielu pokoleń prawników, wybitnemu przedstawicielowi nauki, którego szeroka aktywność i przebogaty dorobek $^{1}$ na wielu polach świadczy o wyjątkowej aktywności i wszechstronności zainteresowań. Uczestnicząc w ponad 50 przewodach doktorskich i habilitacyjnych, a także jako recenzent $\mathrm{w}$ postępowaniach dotyczących nadania tytułu naukowego profesora oraz powołania na stanowisko profesora, Jubilat zawsze wykazywał się uczciwym i rzetelnym podejściem naukowym, czego beneficjentem był także Wydział Prawa Uniwersytetu w Białymstoku. Jest on również jednym z nielicznych i pierwszych prawników-karnistów będących stypendystami Fundacji Alexandra von Humboldta. Piszącym te słowa pozostaje wyrazić radość, że także jako stypendyści, tzw. Humboldtczycy, odbywali swe pobyty stypendialne w miejscach, w których już wcześniej przebywał Jubilat — w Hamburgu, Kolonii, Freiburgu, Bonn, Monachium i Ratyzbonie. Swoje naukowe kontakty z przedstawicielami niemieckiego środowiska karnistycznego Jubilat rozwijał ustawicznie, a jedną z pierwszych inicjatyw kolokwiów polsko-niemieckich było zorganizowanie niemal tuż po transformacji systemowej — w maju 1990 r. w Radkowie Polsko-Niemieckiego Sympozjum Prawa Karnego poświęconego problematyce odpowiedzialności karnej w polskim i niemieckim prawie karnym, z udziałem znakomitych dogmatyków z Polski i Republiki Federalnej Niemiec ${ }^{2}$.

1 Profesor Tomasz Kaczmarek jest autorem ponad 200 prac naukowych z zakresu prawa karnego.

2 Teoretyczne problemy odpowiedzialności karnej w polskim i niemieckim prawie karnym. Materiały Polsko-Niemieckiego Sympozjum Prawa Karnego Karpacz maj 1990, red. T. Kaczmarek, Wrocław 1990. 
Nie sposób nie wspomnieć, że Profesor Tomasz Kaczmarek był także promotorem trzech doktoratów honoris causa prowadzonych na Uniwersytecie Wrocławskim, nadanych profesorom - Witoldowi Świdzie, Friedrichowi Christianowi Schroederowi oraz Leszkowi Kubickiemu. Będąc Uczniem profesora Witolda Świdy, Jubilat jest Mistrzem na miarę swojego Mistrza. Autorzy dedykowanego Profesorowi Tomaszowi Kaczmarkowi tekstu wyrażają nadzieję, że jego lektura sprawi Mu radość i satysfakcję, biorąc pod uwagę, że problematyka funkcji prawa karnego jest Mu także bliska.

II. Wiek XX przyniósł Polsce trzy kodyfikacje karne. Pierwszym kodeksem obowiązującym na terenie Polski niepodległej był kodeks karny z 1932 r. ${ }^{3}$, zwany kodeksem Makarewicza ${ }^{4}$, niezmiernie postępowy jak na owe czasy, wzorowany na najlepszych europejskich standardach. Niestety, jego następca z 1969 r. ${ }^{5}$, zwany kodeksem Andrejewa ${ }^{6}$, opierał się już na doświadczeniach radzieckich, do dnia dzisiejszego zaś obowiązuje, nie do końca udany, kodeks karny z 1997 r. ${ }^{7}$

Kodeks karny z 1932 r. łączył w sobie elementy socjologicznej i klasycznej szkoły prawa, jednak katalog kar zasadniczych i dodatkowych nie przewidywał żadnych środków o charakterze restytucyjnym. Jedynie przy warunkowym zawieszeniu wykonania kary, ukształtowanym na wzór modelu francusko-belgijskiego, przewidziano, że: „Jeżeli stosunki gospodarcze skazanego na to pozwalają, sąd może zobowiązać skazanego, by wynagrodził szkody, zrządzone przestępstwem, w czasie i w rozmiarach ustalonych w wyroku” ${ }^{8}$. Z kolei „Sąd może zasądzić wykonanie zawieszonej kary, jeżeli w okresie zawieszenia kary skazany popełni inne przestępstwo, niż określone w $\S 1$, uchyla się z pod dozoru, źle się prowadzi lub nie wykona obowiązku wynagrodzenia szkody"9.

Na gruncie kodeksu karnego z 1969 r. prezentowane w doktrynie funkcje prawa karnego były ujmowane w ramach węższego bądź szerszego katalogu. Przykładowo I. Andrejew w zasadzie ograniczał się do wyeksponowania dwóch funkcji prawa karnego, tj. gwarancyjnej i ochronnej, wskazując przy tym, że funkcje prawa karnego przeplatają się z funkcjami karania ${ }^{10}$. Z kolei J. Śliwowski w ogóle nie wyodrębniał hasłowo funkcji prawa karnego ze względu na przeniesienie punktu

3 Rozporządzenie Prezydenta Rzeczypospolitej z dnia 11 lipca 1932 r. — Kodeks karny, Dz.U. z 1932 r. Nr 60, poz. 571 ze zm.

4 Od nazwiska jednego z członków Komisji Kodyfikacyjnej — prof. Juliusza Makarewicza.

${ }^{5}$ Ustawa z dnia 19 kwietnia 1969 r. — Kodeks karny, Dz.U. z 1969 r. Nr 13, poz. 94 ze zm.

${ }^{6}$ Od nazwiska Profesora Igora Andrejewa.

${ }^{7}$ Ustawa z dnia 6 czerwca 1997 r. — Kodeks karny, Dz.U. z 1997 r. Nr 88, poz. 553 ze zm. Tekst jednolity Dz.U. z 2016 r. poz. 1137.

8 Art. $62 \S 2$ k.k.

9 Art. 63 § 2 k.k.

10 I. Andrejew, Polskie prawo karne w zarysie, Warszawa 1983, s. 34-35. 
ciężkości rozważań na problematykę kary kryminalnej i jej „funkcję ochronną"11. C. Gofroń w katalogu funkcji prawa karnego wymieniał w kolejności funkcje: ochronną, gwarancyjną, represyjną i prewencyjną. Zaznaczał jednocześnie, iż $\mathrm{z}$ tego, że prawo karne spełnia rolę pomocniczą $\mathrm{w}$ walce ze społecznie ujemnymi czynami, wypływają dalsze jego właściwości polegające na tym, że nie można się w nim dopatrywać wprost jakiejś funkcji organizacyjnej. Można ją wszakże widzieć pośrednio w tym sensie, że ułatwia ono i zabezpiecza realizowanie tejże funkcji innym dziedzinom prawa ${ }^{12}$.

A. Marek eksponował natomiast trzy funkcje prawa karnego: ochronną, gwarancyjną i prewencyjno-wychowawczą ${ }^{13}$. Z kolei K. Buchała w katalogu tych funkcji ujmował w kolejności funkcje: ochronną, prewencyjno-wychowawczą, represyjną, profilaktyczno-zabezpieczającą oraz gwarancyjną, odwołując się przy tym do dość zgodnego w doktrynie przekonania, iż funkcja ochronna jest „,podstawową funkcją prawa karnego"14. Piętnaście lat później ten sam autor, wspólnie z A. Zollem, wyszczególnił jedynie dwie funkcje prawa karnego, tj. ochronną i gwarancyjną ${ }^{15}$. W podobnej konwencji i w takiej samej kolejności ujmował funkcje prawa karnego w swoich podręcznikach opublikowanych w latach 80 . W. Świda ${ }^{16}$. Wynika $\mathrm{z}$ tego, że doktryna nie przywiązywała wagi do funkcji restytucyjnej na tle kodeksu karnego z 1969 r. ${ }^{17}$

Jednak wypada zauważyć, że na tle tego kodeksu obowiązywały pewne rozwiązania, które wskazywały na restytucyjną funkcję prawa karnego. Przykładowo, umarzając warunkowo postępowanie karne, sąd mógł zobowiązać sprawcę do naprawienia w całości albo w części szkody wyrządzonej przestępstwem, jeśli zarzut zaś dotyczył przestępstwa przeciwko mieniu, sąd obligatoryjnie zobowiązywał do naprawienia szkody. ${ }^{18}$ Jeżeli sprawca szkody by nie naprawił, fakt ten był podstawą do obligatoryjnego podjęcia postępowania warunkowo umorzonego ${ }^{19}$. Innym przykładem funkcji restytucyjnej był kształt kary ograniczenia wolności. Wymierzając tę karę, sąd mógł zobowiązać sprawcę do naprawienia w całości albo w części szkody wyrządzonej przestępstwem lub/i do przeproszenia pokrzywdzo-

11 J. Śliwowski, Prawo karne, wyd. drugie, Warszawa 1979, s. 3 n.

12 C. Gofroń, Pojęcia wstępne, [w:] T. Bojarski et al., Prawo karne, Lublin 1994, s. 14 n.

13 A. Marek, Wiadomości wstępne, [w:] Prawo karne. Zagadnienia teorii i praktyki, red. A. Marek, Warszawa 1986, s. 12-13.

14 K. Buchała, Prawo karne materialne, Warszawa 1980, s. 22 n.

15 K. Buchała, A. Zoll, Polskie prawo karne, Warszawa 1995, s. 11-14.

16 Zob. W. Świda, Prawo karne, Warszawa 1986, s. 13-14; idem, Prawo karne, Warszawa 1989, s. 13-14.

17 Szeroko na ten temat, zob. E.W. Pływaczewski, Funkcja restytucyjna (kompensacyjna) prawa karnego z perspektywy teorii i praktyki, [w:] Wspótczesne problemy prawa, t. 1, red. I. Nowicka, D. Mocarska, Szczytno 2015, s. 21.

18 Art. 28 k.k.

19 Art. 29 k.k. 
nego ${ }^{20}$. Funkcja kompensacyjna widoczna była także przy warunkowym zawieszeniu wykonania kary. Sąd mógł zobowiązać skazanego do naprawienia w całości albo w części szkody wyrządzonej przestępstwem lub/i do przeproszenia pokrzywdzonego, przy czym w odniesieniu do sprawcy zagarnięcia mienia społecznego naprawienie szkody było obligatoryjną przesłanką pozytywną stosowania tej instytucji probacyjnej ${ }^{21}$. Niewykonanie obowiązku naprawienia szkody stanowiło przesłankę obligatoryjnego zarządzenia wykonania kary ${ }^{22}$.

III. Cytowany już wyżej A. Marek znacznie szerszy katalog funkcji prawa karnego zaprezentował w swoim pierwszym podręczniku, który uwzględniał już rozwiązania zawarte w nowym Kodeksie karnym z 1997 r. (z uwzględnieniem poprawek Senatu uchwalonych w dniu 26 kwietnia 1997 r., przyjętych przez Sejm) ${ }^{23}$. Obok wskazywanych wcześniej funkcji, tj. ochronnej, gwarancyjnej i prewencyjno-wychowawczej, wymieniał on ponadto takie funkcje, jak: afirmacyjno-motywacyjna, sprawiedliwościowa oraz restytucyjna. W odniesieniu do funkcji restytucyjnej autor ten podkreślał, iż ukształtowała się ona pod wpływem idei ochrony praw człowieka, w tym postulatów wiktymologii. Innymi słowy, prawo karne powinno poprzez odpowiedni system środków karnych umożliwiać sprawcy przestępstwa starania o naprawienie wyrządzonej pokrzywdzonemu szkody ${ }^{24}$.

Funkcję restytucyjną (kompensacyjną) eksponuje również — obok funkcji ochronnej i gwarancyjnej - J. Giezek, wskazując, iż nabrała ona znaczenia po wejściu w życie Kodeksu karnego z 1997 r., którego istotnym rysem charakterystycznym jest wzmocnienie roli i pozycji pokrzywdzonego. Autor podkreśla, iż sprzyjają temu nie tylko regulacje przewidziane w prawie karnym materialnym, lecz także pewne rozwiązania procesowe, np. instytucja mediacji lub ugoda, w wyniku której oskarżony dobrowolnie poddaje się odpowiedzialności ${ }^{25}$. $\mathrm{Z}$ kolei L. Gardocki w katalogu funkcji prawa karnego wymienia kolejno: funkcję sprawiedliwościową, ochronną i gwarancyjną ${ }^{26}$. Natomiast T. Bojarski wskazuje cztery funkcje: sprawiedliwościową, ochronną, profilaktyczno-wychowawczą i gwarancyjną ${ }^{27}$.

W istocie kodeks karny z 1997 r. jest aktem najpełniej dotychczas realizującym restytucyjną funkcję prawa karnego. Zawiera najszerszy katalog instytucji

20 Art. 35 k.k.

21 Art. 75 k.k.

22 Art. 78 k.k.

23 A. Marek, Prawo karne. Zagadnienia teorii i praktyki, Warszawa 1997, s. 14 n.

24 Ibidem, s. 16.

25 J. Giezek, Pojęcie i funkcje prawa karnego, [w:] M. Bojarski, J. Gierek, Z. Sienkiewicz, Prawo karne materialne. Czesść ogólna i szczególna, red. M. Bojarski, wyd. 4, Warszawa 2010, s. $26 \mathrm{n}$.

26 L. Gardocki, Prawo karne, wyd. 9, Warszawa 2003, s. 6-7.

27 T. Bojarski, Polskie prawo karne. Zarys części ogólnej, Warszawa 2008, s. 29. 
kompensacyjnych, ujmując po raz pierwszy w historii w swoim pierwotnym tekście obowiązek naprawienia szkody jako środek karny ${ }^{28}$. Od dnia 1 lipca 2015 r. wprowadzono do kodeksu karnego rozdział Va, który zatytułowano jako: „Przepadek i środki kompensacyjne”. Srodki kompensacyjne to obowiązek naprawienia w całości albo w części szkody wyrządzonej przestępstwem, zadośćuczynienie za doznaną krzywdę, nawiązka na rzecz pokrzywdzonego, na rzecz Funduszu Pomocy Pokrzywdzonym oraz Pomocy Postpenitencjarnej lub na rzecz Narodowego Funduszu Ochrony Środowiska i Gospodarki Wodnej.

W uzasadnieniu dokonanych zmian można przeczytać, że:

zmiana art. 46 zmierza do ułatwienia uzyskania przez pokrzywdzonego pełnego zaspokojenia roszczeń cywilnoprawnych wynikających z popełnionego przestępstwa. Celem jest orzekanie w ramach procesu karnego na podstawie przepisów prawa cywilnego, poza możliwością zasądzenia renty, obowiązku naprawienia w całości lub w części wyrządzonej przestępstwem szkody. Alternatywą dla tej drogi uzyskania kompensaty lub zadośćuczynienia jest orzeczenie przez sąd karny, kierujący się w tym wypadku podobną metodą szacowania szkody i krzywdy, ale działający w ramach swojej karnoprawnej kompetencji, nawiązki na rzecz pokrzywdzonego lub — w razie jego śmieci — na rzecz osoby najbliższej, której sytuacja życiowa wskutek śmierci pokrzywdzonego uległa znacznemu pogorszeniu. Szersze ujęcie katalogu osób najbliższych w opisywanej sytuacji śmierci pokrzywdzonego nieproporcjonalnie zwiększyłoby obowiązki naprawcze skazanego.

Wprowadzenie tej zmiany umożliwia rezygnację z powództwa adhezyjnego, czego wynikiem jest nowelizacja odpowiednich jednostek redakcyjnych Kodeksu postępowania karnego. [...] Mimo, że środek z art. $46 \S 1$ k.k. nie ma charakteru karnego, projektodawca przewiduje wciąż możliwość orzeczenia odszkodowania zarówno w pełnej wysokości, jak również tylko w zakresie częściowo pokrywającego szkodę. Podobnie jak orzekanie nawiązki zamiast odszkodowania lub zadośćuczynienia nastąpiło z powodów praktycznych, tak rozpatrując sprawę z tej samej perspektywy nie można zobowiązać sądu do prowadzenia postępowania dowodowego poza zakresem aktu oskarżenia w celu ustalenia pełnego zakresu szkody lub krzywdy ponad to, co można ustalić w postępowaniu rozpoznawczym związanym z wniesioną skargą. Odmienne uregulowanie, jakkolwiek teoretycznie spójne, nie jest celowe ze względu na negatywny wpływ, jaki może mieć na zdolność koncentracji rozprawy i ekonomiki postępowania karnego. W art. $46 \S 3$ przewidziana jest możliwość dochodzenia niezaspokojonej części roszczenia w drodze procesu cywilnego. W art. 48 k.k. przewidziano zwiększenie wysokości nawiązki, o ile ustawa nie będzie zawierała regulacji odmiennej ${ }^{29}$.

IV. O ile funkcja kompensacyjna na tle kodeksu karnego przejawiała się w obowiązkach nakładanych na sprawcę, o tyle tzw. ustawa kompensacyjna ${ }^{30}$ nakłada określone obowiązki na państwo. Jest ona nie tylko wyrazem funkcji restytucyjnej, lecz także ochronnej, gdyż państwo ma obowiązek chronić obywatela i jego dobra, a w przypadku gdy czyni to w sposób nieprawidłowy, powinno ponosić związane z tym konsekwencje. Warto nadmienić, iż pierwotna regulacja

28 Art. 39 k.k.

29 http://www.law.uj.edu.pl/ kpk/strona/wp-content/uploads/2015/01/Druk-2393-wersjapierwotna-uzasadnienie.pdf (dostęp: 1.01.2017).

30 Tekst jedn. Dz.U. z 2016 r. poz. 325. Zwana dalej ustawą kompensacyjną. 
omawianej ustawy została zmieniona w 2009 r. W wyniku nowelizacji dokonanej ustawą z dnia 3 kwietnia 2009 r. o zmianie ustawy o państwowej kompensacie przysługującej ofiarom niektórych przestępstw umyślnych ${ }^{31}$ poszerzony został krąg osób uprawnionych do kompensaty o pokrzywdzonych przestępstwami nieumyślnymi. Ponadto przyjęto, że środki z kompensaty mogą być również przeznaczone na rehabilitację. Do postępowań w sprawie o kompensatę, wszczętych przed dniem wejścia w życie wskazanych zmian, pozostawały w mocy przepisy dotychczas obowiązujące. Na mocy dokonanej nowelizacji tytuł ustawy otrzymał brzmienie: „O państwowej kompensacie przysługującej ofiarom niektórych przestępstw".

Przepisy ustawy kompensacyjnej były szczegółowo analizowane zarówno przez przedstawicieli doktryny, jak i praktyki, którzy zajmowali wobec nich stanowisko raczej krytyczne ${ }^{32}$. W 2012 r. zaprezentowane zostały wyniki pierwszych badań na temat działania tej ustawy ${ }^{33}$. Przeprowadziła je L. Mazowiecka, prokurator w Prokuraturze Generalnej, a ich zasadniczym celem było ustalenie, jak kształtuje się w praktyce orzecznictwo sądowe dotyczące państwowej kompensaty, jak również czy sama instytucja państwowej kompensaty jest zrozumiała dla osób do niej uprawnionych oraz organów procesowych ${ }^{34}$.

Badania wykazały, że skala, w jakiej jest wykorzystywana możliwość ubiegania się o kompensatę, jest niewielka, albowiem w analizowanym okresie 20052009 średnio rocznie sądy rozpatrywały zaledwie 96 wniosków o przyznanie kompensaty. Wystąpiła tu więc rażąca dysproporcja między przewidywaniem projektodawcy, że o kompensatę może ubiegać się rocznie blisko 13000 osób, a realiami praktyki. Jednocześnie wraz z systematycznie spadającą liczbą przyznawanych kompensat (w 2005 r. nie przyznano kompensaty w ogóle, w 2006 r. — 30, w 2007 r. — 49, w 2008 r. — 47, w 2009 r. — 26) rosła jej wysokość. W 2006 r. średnio wynosiła ona 1 780, 49 zł, a w 2009 r. — już 6 671, 30 zł. Należy jednak przypomnieć, iż zgodnie z przewidywaniami projektodawcy obciążenie Skarbu Państwa z tytułu wypłat kompensaty miało wynosić 70 mln zł. W rzeczywistości obciążenie to wynosiło średnio zaledwie $0,2 \%$ przewidywanej kwoty ${ }^{35}$. Wyniki badań prowadzą do jednoznacznego w swojej wymowie wniosku, który L. Mazowiecka wyartykułowała następująco: uzyskanie kompensaty na podstawie obowiązujących przepisów nie tylko nie łagodzi zjawiska wiktymizacji pierwotnej,

31 Dz.U. z dnia 28 maja 2009 r. Nr 79, poz. 665. Zob. też Dz.U. 2008 Nr 96, poz. 608.

32 Zob. np. L. Mazowiecka, Państwowa kompensata dla ofiar przestępstw, Warszawa 2012; E. Bieńkowska, Prawa ofiar przestępstw, Warszawa 2009; eadem, Państwowa kompensata przysługujaca ofiarom niektórych przestęstw. Komentarz, Warszawa 2011.

33 Przedstawiono je na konferencji, która odbyła się w Prokuraturze Generalnej w dniu 22 lutego $2012 \mathrm{r}$.

34 Szeroką relację z tych badań L. Mazowiecka zawarła w opracowaniu pt. Kompensata państwowa w Polsce, opublikowanym w dwumiesięczniku „Niebieska Linia” 2012, nr 2/79.

35 Ibidem, s. 19. 
jak postuluje wiktymologia, lecz wręcz przeciwnie — jest źródłem wiktymizacji wtórnej ${ }^{36}$.

Emil W. Pływaczewski sformułował pewne wnioski natury bardziej ogólnej, eksponując rolę badań kryminologicznych i znaczenie ich wyników dla optymalizacji rozwiązań prawnych. Wyniki tego rodzaju badań bywają bardzo często niewygodne dla polityków, gdyż odsłaniają one różnego rodzaju nieprawidłowości zarówno w regulacjach prawnych, jak i praktyce ich stosowania. Przy podejściu zdroworozsądkowym należałoby jak najszybciej dokonywać postulowanych zmian. $Z$ reguły tak się jednak nie dzieje. Na ogół powodem zaniechań w tym względzie jest brak woli politycznej wynikającej z koniunkturalizmu, kłopotów budżetowych itp. Jest to „strategia” krótkowzroczna, generująca w dłuższej perspektywie jeszcze większe koszty, nie mówiąc już o szeroko rozumianych szkodach społecznych. Patologiczny stan prawny wygenerowany ustawą o państwowej kompensacie utrzymuje się już od wielu lat ${ }^{37}$.

Wydaje się, że postulaty różnych środowisk, w tym środowiska naukowego, zostały w pewnej mierze dostrzeżone, albowiem pomimo marginalnego praktycznego znaczenia ustawy kompensacyjnej ustawodawca zdecydował się na jej kolejną nowelizację ${ }^{38}$, co wypada ocenić pozytywnie. Nowelizacja weszła w życie 13 stycznia 2016 r. ${ }^{39}$ Jak można przeczytać w uzasadnieniu, wówczas jeszcze projektu ustawy, przedmiotem nowelizacji była gruntowna przebudowa przepisów ustawy z dnia 7 lipca 2005 r. o państwowej kompensacie przysługującej ofiarom niektórych przestępstw, której potrzeba wynikła z praktyki orzeczniczej sądów, związanej z realizacją tej ustawy w zakresie wynikającym z informacji o działalności Rzecznika Praw Obywatelskich za rok 2012 wraz z uwagami o stanie przestrzegania wolności oraz praw człowieka i obywatela.

W stanowisku skierowanym do Marszałka Senatu RP Rzecznik Praw Obywatelskich wyraził poważny niepokój wynikający z obserwacji efektywności wykonywania przedmiotowej ustawy i stwierdził, że ustawa o państwowej kompensacie przysługującej ofiarom niektórych przestępstw nie tylko nie gwarantuje skutecz-

${ }^{36}$ L. Mazowiecka, Kompensata państwowa..., s. 22.

37 E.W. Pływaczewski, op. cit., s. 35.

38 Ustawa do października 2016 r. była nowelizowana trzykrotnie - ustawą z dnia 11 kwietnia 2008 r. o zmianie ustawy o państwowej kompensacie przysługującej ofiarom niektórych przestępstw umyślnych, Dz.U. z 2008 r. Nr 96, poz. 608; ustawą z dnia z dnia 3 kwietnia 2009 r. o zmianie ustawy o państwowej kompensacie przysługującej ofiarom niektórych przestępstw umyślnych, Dz.U. z 2009 r. Nr 79, poz. 665 oraz ustawą z dnia z dnia 5 sierpnia 2015 r. o zmianie ustawy o państwowej kompensacie przysługującej ofiarom niektórych przestępstw, ustawy - Kodeks postępowania cywilnego oraz ustawy o kosztach sądowych w sprawach cywilnych, Dz.U. z 2015 r. poz. 1587.

39 Ustawa z dnia 5 sierpnia 2015 r. o zmianie ustawy o państwowej kompensacie przysługującej ofiarom niektórych przestępstw, ustawy - Kodeks postępowania cywilnego oraz ustawy o kosztach sądowych w sprawach cywilnych, Dz.U. z 2015 r. poz. 1587. 
nej pomocy osobom pokrzywdzonym przestępstwem, lecz często powoduje ich wtórną wiktymizację.

W tym stanie rzeczy Rzecznik Praw Obywatelskich zaapelował o rozważenie podjęcia działań, które spowodowałyby poprawę tego niepożądanego stanu prawnego tak, by prawa ofiar przestępstw i ich godność były należycie chronione.

Celem nowelizacji było poszerzenie zakresu podmiotowego ustawy, usunięcie lub zmiana przepisów niejasnych, sprzecznych z wiążącym Polskę prawem międzynarodowym, dodanie unormowań, które podwyższą maksymalną kwotę kompensaty, umożliwią domaganie się zaliczki na poczet koniecznych wydatków bieżących, wydłużą termin składania wniosku o wypłatę kompensaty, wprowadzą prawo występowania o wypłatę kompensaty osobie, pod której pieczą pozostaje ofiara przestępstwa, oraz poprzez zmianę właściwości miejscowej organu orzekającego i organu pomocniczego uproszczą dochodzenie kompensat osobom poszkodowanym $^{40}$.

Analiza wykazała, że wiele przepisów ustawy o państwowej kompensacie przysługującej ofiarom niektórych przestępstw jest niezgodnych z prawem unijnym, a wiele wzajemnie ze sobą sprzecznych do takiego stopnia, że dostęp do kompensaty państwowej stał się w praktyce iluzoryczny.

$\mathrm{Z}$ przedłożonych Senatowi informacji na temat działania ustawy kompensacyjnej wynika, że sądy rozpatrzyły (w latach 2006-2013) łącznie 1449 wniosków, przyznając kompensatę w 350 przypadkach, co stanowi jedną piątą ogółu załatwionych spraw i oznacza przyznanie średnio 44 kompensat rocznie. Przewidywane w ustawie budżetowej m.in. na ten cel środki w wysokości $70 \mathrm{mln}$. zł wykorzystywane były w $0,2 \%$ przewidywanej sumy (w samym 2013 r. było to $0,4 \%$ ).

Takie efekty realizacji przepisów ustawy kompensacyjnej wynikają z niedoskonałości przepisów oraz licznych nieprawidłowości postępowań prowadzonych w tych sprawach. Do najpoważniejszych słabości rozwiązań przyjętych w ustawie zaliczyć należy: 1) brak możliwości złożenia wniosku o przyznanie kompensaty przez osobę najbliższą, gdy ofiara w wyniku przestępstwa stała się całkowicie niesprawna, a jednocześnie nie jest ubezwłasnowolniona; 2) brak możliwości uzyskania zaliczki na pokrycie kosztów związanych z usuwaniem szkód powstałych wskutek przestępstwa i preferowanie osób zamożnych poprzez żądanie uprzedniego wydatkowania kwot i przedstawiania sądowi rachunków już zrealizowanych świadczeń; 3) zbyt krótki termin na złożenie wniosku o kompensatę; 4) zbyt niskie kwoty przyznawanych kompensat i niejednolitość orzekanych kwot w podobnych przypadkach, co wynikać może z braku taryfikatora świadczeń oraz braku dolnej granicy kompensaty, w efekcie bardzo często koszty postępowania znacznie przekraczają wartość przyznanej kompensaty ${ }^{41}$.

40 Druk Sejmowy nr 3078, http://orka.sejm.gov.pl/Druki7ka.nsf/0/23E443EA7DB0EFAAC1 257DCD004B07A1/\%24File/3078.pdf (dostęp: 1.01.2017).

${ }^{41}$ Ibidem. 
Wiele znowelizowanych rozwiązań ma swoje źródło w aktach prawa międzynarodowego, które wytyczają drogę pomocy ofiarom przestępstw w ustawodawstwach krajowych. Pierwszym z tych aktów prawnych jest Europejska konwencja o kompensacji dla ofiar przestępstw popełnionych z użyciem przemocy z dnia 24 listopada 1983 r., której, niestety, do chwili obecnej Polska, będąc członkiem Rady Europy, nie ratyfikowała.

Pierwsza $\mathrm{z}$ wprowadzanych zmian polega na rezygnacji $\mathrm{w}$ tytule $\mathrm{i} \mathrm{w}$ treści ustawy z pojęcia „przestępstwa” na rzecz „,czynu zabronionego”. Zabieg taki jest konieczny ze względu na możliwość występowania z wnioskiem o przyznanie kompensaty w sytuacji, gdy sprawca czynu nie może być oskarżony ani skazany chociażby w sytuacjach, w których sprawcy nie można przypisać winy. Kolejne wprowadzone w ustawie zmiany obejmują definicje „ofiary”, „osoby najbliższej” oraz „osoby uprawnionej”. Nowe definicje w sposób przejrzysty określają krąg podmiotowy ustawy kompensacyjnej.

Przepis art. 2 pkt 1 lit. b zmienionej ustawy określa jedno z podstawowych kryteriów pozwalających na ubieganie się o kompensatę. Jest nim wystąpienie u ofiary czynu zabronionego ciężkiego uszczerbku na zdrowiu, naruszenia czynności narządu ciała lub rozstroju zdrowia, o których mowa w art. $156 \S 1$ lub w art. $157 \S 1$ Kodeksu karnego. Kolejna zmiana usuwa z przepisu warunek wystąpienia $\mathrm{z}$ wnioskiem o kompensatę $\mathrm{w}$ postaci pozostawania osoby najbliższej na utrzymaniu ofiary, która w wyniku czynu zabronionego poniosła śmierć.

Zmieniona ustawa kompensacyjna w art. 6 zakreśliła jedynie maksymalną wysokość kompensaty. Określona we wcześniejszym brzmieniu przepisu kwota 12 tys. zł nie dawała sądowi możliwości odzwierciedlenia w orzekanej kompensacie rzeczywistej straty poniesionej przez ofiarę. Zdarzało się, że identyczna suma przyznawana jest za uszczerbek na zdrowiu z art. 157 k.k. oraz w przypadku śmierci ofiary. Przy takich kwotach przyznanie kompensaty miało raczej wymiar symboliczny. Ustawodawca podwyższył tę kwotę do 25 tys. zł, a w przypadku gdy ofiara czynu zabronionego zmarła — kwoty 60 tys. zł.

Należy przy tym pamiętać, że kompensata nie ma charakteru zadośćuczynienia, a jedynie służy pokryciu kosztów czy utraconych zarobków. W art. 5 ustawa stanowi, że prawo do kompensaty przysługuje niezależnie od tego czy sprawca lub sprawcy przestępstwa zostali wykryci, oskarżeni lub skazani. Art. 7a ust. 2 przewiduje odmowę przyznania kompensaty, gdy ofiara była współsprawcą czynu zabronionego, z którego wywodzi swoje uprawnienie (np. w przypadku wniosku o przyznanie kompensaty wniesionego przez uczestnika bójki). Przyznanie kompensaty jest również wyłączone w przypadkach godzenia się na ryzyko doznania skutków czynu zabronionego, przez co należy rozumieć przypadki np. ryzyka sportowego (nielegalne walki lub wyścigi) oraz zgodę pokrzywdzonego na naruszenie jego praw.

Ustawa kompensacyjna zawiera wydłużenie terminu do złożenia wniosku do 3 lat od dnia ujawnienia się skutków czynu zabronionego, nie później jednak niż 
5 lat od dnia jego popełnienia. Zmiana ta jest odpowiedzią na podnoszone głosy praktyków, iż w efekcie traumatycznego przeżycia, jakim było dla ofiary przestępstwo, czas potrzebny na leczenie, rehabilitację i obiektywną ocenę skutków tych zdarzeń, może być niewystarczający na podjęcie właściwych decyzji i dochodzenie kompensaty w wyznaczonym ustawą czasie. Jednym z najbardziej oczekiwanych rozwiązań było wprowadzenie możliwości uzyskania zaliczki na poczet kompensaty, na pokrycie niezbędnych kosztów leczenia, rehabilitacji lub pogrzebu.

Projektodawcy zakładali, że przewidywanym i oczekiwanym skutkiem prawnym projektowanej ustawy kompensacyjnej będzie zwiększenie ilości pozytywnie rozpatrzonych wniosków o przyznanie kompensaty oraz podwyższenie sum przyznawanych w tych sprawach ${ }^{42}$. Wypada mieć nadzieję, że rzeczywiście tak się stanie.

V. Współcześnie w dyskusję tę wpisuje się pogląd Szacownego Jubilata, który już ponad ćwierćwiecze temu dostrzegał potrzebę łączenia badań dogmatycznych z kontekstem społecznym, którego dotyczą. W 1990 r. Profesor Tomasz Kaczmarek pisat:

Próby przezwyciężenia [...] formalizmu w prawie, będącego wynikiem czysto logicznej interpretacji zjawisk prawnych, sprawiają w efekcie, że fakty społeczne, do których odnoszą się normy prawa karnego i znaczenie normatywne pojęć używanych w tym prawie coraz częściej konfrontowane są ze znaczeniem, jakie nabierają one na gruncie także innych nauk społecznych. Taki sposób podejścia badawczego zdaje się sprzyjać, jeśli nie rozwiązywaniu, to z całą pewnością formułowaniu nowych problemów badawczych, przy których rozwijanie nowoczesnej dogmatyki prawa karnego nie będzie przypominało przestawiania tych samych mebli w starym mieszkaniu ${ }^{43}$.

Wskazuje to w prostej linii na konieczność analizy efektywności stanowionych norm prawa karnego w płaszczyźnie społecznej i wręcz obowiązek konfrontowania regulacji prawnokarnych z praktyką ich stosowania w rzeczywistości społecznej. Znakomicie widać to na przykładzie omawianej ustawy kompensacyjnej z dnia 7 lipca $2005 \mathrm{r}$.

\section{A few remarks on a compensative function of criminal law}

\section{Summary}

The article is divided into four parts, presenting a restitutive function, from a historical perspective, of compensation in the view of the Criminal Code of 1997, as well as in the view of the Act of 7 July 2005 on State compensation granted to victims of certain prohibited acts. The authors also attempt to summarize and evaluate the amendment. The article is dedicated to the Esteemed

\footnotetext{
42 Ibidem.

43 T. Kaczmarek [w:] Teoretyczne problemy...., s. 3-4.
} 
Professor Tomasz Kaczmarek, celebrating His jubilee, an Educator of generations of lawyers, an Outstanding representative of the science, whose wide activity and plenteous achievements in various fields indicate great versatility of His interests.

Keywords: functions of criminal law, forfeiture and compensation measures, victim of crime. 